\title{
FACTORS INFLUENCING THE ANTIBIOTIC ACTIVITY OF LUPULON ${ }^{1,2,3}$
}

\author{
By YIN-CH'ANG CHIN, NAI-CH'U CHANG,4 AND HAMILTON H. ANDERSON \\ (Division of Pharmacology and Experimental Therapeutics, University of Califormia Medical \\ School, San Francisco, California)
}

Lupulon is one of the two lipid-soluble antibiotics prepared from hops (Humulus lupulus L.) $(1,2)$. Michener et al. reported antifungal activity for both lupulon and humulon. Salle et al. (3) confirmed Shimwell (4), that Gram-positive organisms are more susceptible to lupulon than are Gram-negative bacteria. Chin et al. (5) reported its antituberculous activity both in vitro and in vivo. These findings and its relatively low toxicity (6) indicated that lupulon may be an effective chemotherapeutic agent. It becomes, therefore, desirable to investigate some important factors which may influence its activity either in vitro or in vivo.

\section{MATERIALS AND METHODS}

Crystalline lupulon used throughout this experiment was prepared at the Western Regional Research Laboratory, Albany, California. One \% solution can be made in alkaline water at $\mathrm{pH}$ around 11.5 or by dissolving the crystals first as $10 \%$ solution in ethyl alcohol and then diluting up to volume with propylene glycol. The antibiotic activity has been found to be the same whether the solution was first made in alkaline water or in propylene glycol. The latter solution has a $\mathrm{pH}$ at 4.8 and has been used, freshly prepared with aseptic precautions, as the stock for further dilutions in alkaline water, serum, or culture media.

Staphylococcus aureus (FDA No. 209), Mycobacterium phlei, and Mycobacterium tuberculosis $\mathrm{H} 37 \mathrm{Rv}$ were used in the experiments. Unless otherwise mentioned, vealglucose broth (7) was used for growth of and tests on Staph. aureus, and Dubos and Davis fluid medium (8) for the mycobacteria. The Coleman junior spectrophotometer was used for turbidimetric determinations of the growth of organisms.

1 Presented at the Second National Symposium on Recent Advances in Antibiotics Research held in Washington, D. C., April 11-12, 1949, under the auspices of the Antibiotics Study Section, National Institutes of Health, Public Health Service, Federal Security Agency.

2 Part of a cooperative study with Drs. J. Lewis and G. Alderton, Western Regional Research Laboratory, U. S. Department of Agriculture, Albany, California.

s Supported, in part, by Eli Lilly and Company, Indianapolis 6, Indiana.

- Peiping Union Medical College Fellow in Pharmacology.

\section{RESULTS}

Effect of size of inoculum. The effect of the size of inoculum of Staph. aureus on the antibiotic activity of lupulon was studied with the serial dilution method. Two-fold dilutions of the antibiotic were made in $0.5 \mathrm{ml}$. of the medium in nine $10-\mathrm{cm}$. test tubes, starting from a concentration of $200 \mu \mathrm{g} . / \mathrm{ml}$. A tenth tube containing the same amount of the medium served as the control in a series. Each tube was then inoculated with $1.5 \mathrm{ml}$. of a diluted 24-hour culture. Each of four different dilutions, namely', $1: 100,1: 1000,1: 10,000$, and $1: 1,000,000$, was inoculated to one series of tubes. The tubes were incubated at $37^{\circ} \mathrm{C}$. and observations were made four, 24 , and 48 hours later. The results are shown in Table I where even a faint growth was recorded positive.

Apparently the end point of no growth varied with the concentrations of the inoculum and also the time when the observation was made. Repeated experiments showed that observations at four hours after inoculation gave consistent end point at $1: 640,000$ or $1.56 \mu \mathrm{g} . / \mathrm{ml}$. in the series where the concentration of the inoculum was $1: 1,000$ of a 24-hour culture. This size of inoculum and time of incubation have been adopted in later experiments where serial dilution method was used.

Effect of constitution of medium. The serial dilution method was used to determine the bacteriostatic level of lupulon against Staph. aureus in three different media. These media, ${ }^{\mathbf{B}}$ namely,

5 The compositions of these media are given below:

Modified Dubos and Davis medium:

Casein hydrolysate

$1.0 \mathrm{gm}$.

$\mathrm{Na}_{2} \mathrm{HPO}_{4} \cdot 12 \mathrm{H}_{2} \mathrm{O}$

$6.3 \mathrm{gm}$.

$\mathrm{KH}_{2} \mathrm{PO}$,

$1.0 \mathrm{gm}$.

$\mathrm{Na}_{2}$ citrate $\cdot 2 \mathrm{H}_{2} \mathrm{O}$

$1.5 \mathrm{gm}$.

$\mathrm{MgSO} \cdot 7 \mathrm{H}_{2} \mathrm{O}$

$0.6 \mathrm{gm}$.

Distilled water to

$1000.0 \mathrm{ml}$.

Beef heart infusion broth:

Beef heart

Difco neopeptone

$500 \mathrm{gm}$.

$10 \mathrm{gm}$. 
TABLE I

The effect of size of inoculum of Staph. aureus on its growth in various concentrations of lupulon at $37^{\circ} \mathrm{C}$.

\begin{tabular}{|c|c|c|c|c|c|c|c|c|c|c|c|}
\hline \multirow{2}{*}{$\begin{array}{l}\text { Concentration } \\
\text { of the inoculum }\end{array}$} & \multirow{2}{*}{$\begin{array}{c}\text { Hours of } \\
\text { incubation }\end{array}$} & \multicolumn{10}{|c|}{ Concentration of lupulon, $\mu \mathrm{g} . / \mathrm{ml}$. } \\
\hline & & 50.0 & 25.0 & 12.5 & 6.25 & 3.12 & 1.56 & 0.78 & 0.39 & 0.20 & 0 \\
\hline $1: 1,000,000$ & $\begin{array}{r}4 \\
24 \\
48\end{array}$ & $\bar{z}$ & $\bar{z}$ & $\bar{z}$ & $\bar{z}$ & $\bar{t}$ & $\bar{t}$ & & $\begin{array}{l}\overline{+}+ \\
++\end{array}$ & $\overline{+}++$ & \\
\hline $1: 10,000$ & $\begin{array}{r}4 \\
24\end{array}$ & $\overline{-}$ & $\overline{-}$ & - & - & & & & & & \\
\hline $1: 1,000$ & $\begin{array}{r}48 \\
4 \\
24\end{array}$ & $\bar{z}$ & $\bar{z}$ & $\bar{z}$ & $\bar{z}$ & \pm & $\frac{+}{t}+$ & & $\begin{array}{l}+ \\
+ \\
+\end{array}$ & $\begin{array}{l}+++ \\
++ \\
++\end{array}$ & \\
\hline $1: 100$ & $\begin{array}{r}48 \\
4 \\
24 \\
48\end{array}$ & $\bar{z}$ & $\bar{z}$ & $\bar{z}$ & $\bar{z}$ & $\begin{array}{l}++ \\
+ \\
+ \\
+\end{array}$ & $\begin{array}{l}+t+ \\
+ \\
++ \\
++\end{array}$ & & $\begin{array}{l}++ \\
++ \\
++ \\
++\end{array}$ & $\begin{array}{l}++ \\
++ \\
++ \\
++\end{array}$ & $\begin{array}{l}+t \\
+t \\
+t \\
+\end{array}$ \\
\hline
\end{tabular}

modified Dubos and Davis medium, a beef heart infusion, and veal-glucose broth, had been shown by turbidimetry to support the growth of Staph. aureus to different extents. It was found, however, that the growth was completely inhibited by lupulon at the same concentration, $1.56 \mu \mathrm{g} . / \mathrm{ml}$., no matter in which medium this antibiotic was incorporated.

\section{Effect of $p H$}

Studied with Staph. aureus. Veal-glucose medium was titrated to $\mathrm{pH}$ 's 7.1, 7.6 and 8.1. For each $\mathrm{pH}$ duplicate series of six tubes were used. Into each of the six tubes in a series, $3 \mathrm{ml}$. of the medium was dispensed, containing an appropriate amount of lupulon so that after the inoculum was added to it the final concentrations of lupulon were $0,0.2,0.4,0.6,0.8$, and $1.0 \mu \mathrm{g} . / \mathrm{ml}$. An inoculum consisted of $3 \mathrm{ml}$. of $1: 50$ dilution of a 24 hour culture so that the final concentration of the bacteria in each tube was 1:100 of the culture. The growth in each tube was measured turbidimetrically after four hours incubation at $37^{\circ} \mathrm{C}$. The results, as shown in Figure 1, indicated greater inhibitory power of lupulon at lower $\mathrm{pH}$.

Plate-well assay was performed by following Pratt and Dufrenoy's method (9), with some

$\begin{array}{lr}\mathrm{NaCl} & 5 \mathrm{gm} . \\ \text { Distilled water } & 1000.0 \mathrm{ml} . \\ \text { Veal-glucose broth: } & \\ \text { Veal infusion } & 500.0 \mathrm{gm} . \\ \text { Bacteriological peptone } & 10.0 \mathrm{gm} . \\ \mathrm{NaCl} & 5.0 \mathrm{gm} . \\ \text { Dextrose } & 1.0 \mathrm{gm} . \\ \text { Distilled water } & 1000.0 \mathrm{ml} .\end{array}$

modifications. The inoculum of Staph. aureus of the top agar was $2 \%$. The inhibition zones were measured after overnight incubation at $37^{\circ} \mathrm{C}$., and the staining processes with $1 \%$ potassium ferricyanide and $1 \%$ ferric sulfate were applied only when necessary. Dilutions of lupulon were made in alkaline water adjusted to pH's 7, 8, 10, and 11.5. The inhibition zones produced by $50,20,10$, and $5 \mu \mathrm{g} . / \mathrm{ml}$. were fairly consistently $28,24,21$, and $18 \mathrm{~mm}$. for respective concentrations at all pH's.

Studied with M. phlei. Dubos medium used in this experiment was titrated to $\mathrm{pH}$ 's $5,6,7$, and 8 . The concentrations of lupulon in duplicate series of tubes were $0,30,35,40,45,50,55,60,70$, and 80 $\mu \mathrm{g} . / \mathrm{ml}$. The inoculum was made so that the final concentration of bacteria in a tube was $1: 100$ of a 48-hour culture. The end points, taken as the concentration in which no growth occurred after 24 hours incubation at $37^{\circ} \mathrm{C}$., were $50 \mu \mathrm{g} . / \mathrm{ml}$. for $\mathrm{pH} 7$ and 8 , and $40 \mu \mathrm{g} . / \mathrm{ml}$. for $\mathrm{pH} 5$ and 6 .

Studied with M. tuberculosis $(H 37 R v)$. The experiment was performed in a similar manner to that with $M$. phlei. The concentrations of lupulon in a series of tubes were $0,5,10,15,20,25,30$, and $40 \mu \mathrm{g} . / \mathrm{ml}$., and the inoculum was $0.05 \mathrm{ml}$. of 14-day culture to a volume of $5 \mathrm{ml}$. of the medium. End points were taken at the end of 72 hours: At $\mathrm{pH} 7$ and 8 it was $25 \mu \mathrm{g} . / \mathrm{ml}$; ; at $\mathrm{pH} 6,15 \mu \mathrm{g}$./ ml. The organisms did not grow well at $\mathrm{pH} 5$.

\section{Effect of $\mathrm{NaCl}$}

Studied with Staph. aureus. The veal-glucose medium contains $0.5 \% \mathrm{NaCl}$. The salt concen- 
tration was also increased to 1 and $2 \%$. Since $\mathrm{NaCl}$ itself at concentrations higher than $2 \%$ inhibited partly the growth of the bacteria, they were not included in this experiment. The results of the turbidimetric measurements indicated that $2 \%$ sodium chloride increased slightly the activity of lupulon (Figure 1).

Plate-well assay showed no influence of $0.5,1$, 2 , and $5 \% \mathrm{NaCl}$ on the activity of lupulon when the salt was incorporated in the lupulon solutions. However, as illustrated in Table II slightly larger inhibition zones were produced by the same concentrations of lupulon when the salt was incorporated in the agar plates.
TABLE II

The effect of $\mathrm{NaCl}$ incorporated in agar plates on the activity of lupulon against Staph. aureus

\begin{tabular}{|c|c|c|c|c|}
\hline \multirow{2}{*}{$\begin{array}{c}\text { Concentration } \\
\text { of } \mathrm{NaCl} \text { in agar } \\
\%\end{array}$} & \multicolumn{4}{|c|}{ Concentration of lupulon, $\mu \mathrm{g} . / \mathrm{ml}$. } \\
\hline & 50 & 20 & 10 & 5 \\
\hline & \multicolumn{4}{|c|}{ Average diameter of inhibition zones, $\mathrm{mm}$. } \\
\hline $\begin{array}{l}0.5 \\
1.5 \\
2.5 \\
5.5\end{array}$ & $\begin{array}{l}28 \\
27.5 \\
27.5 \\
27.5\end{array}$ & $\begin{array}{l}24 \\
24 \\
24.5 \\
24.5\end{array}$ & $\begin{array}{l}21 \\
21.2 \\
21.5 \\
22\end{array}$ & $\begin{array}{l}17.5 \\
19 \\
19.5 \\
20.2\end{array}$ \\
\hline
\end{tabular}

Studied with M. tuberculosis $(H 37 R v)$. It has also been shown by experiment, as described previously, that $2 \%$ sodium chloride increased the

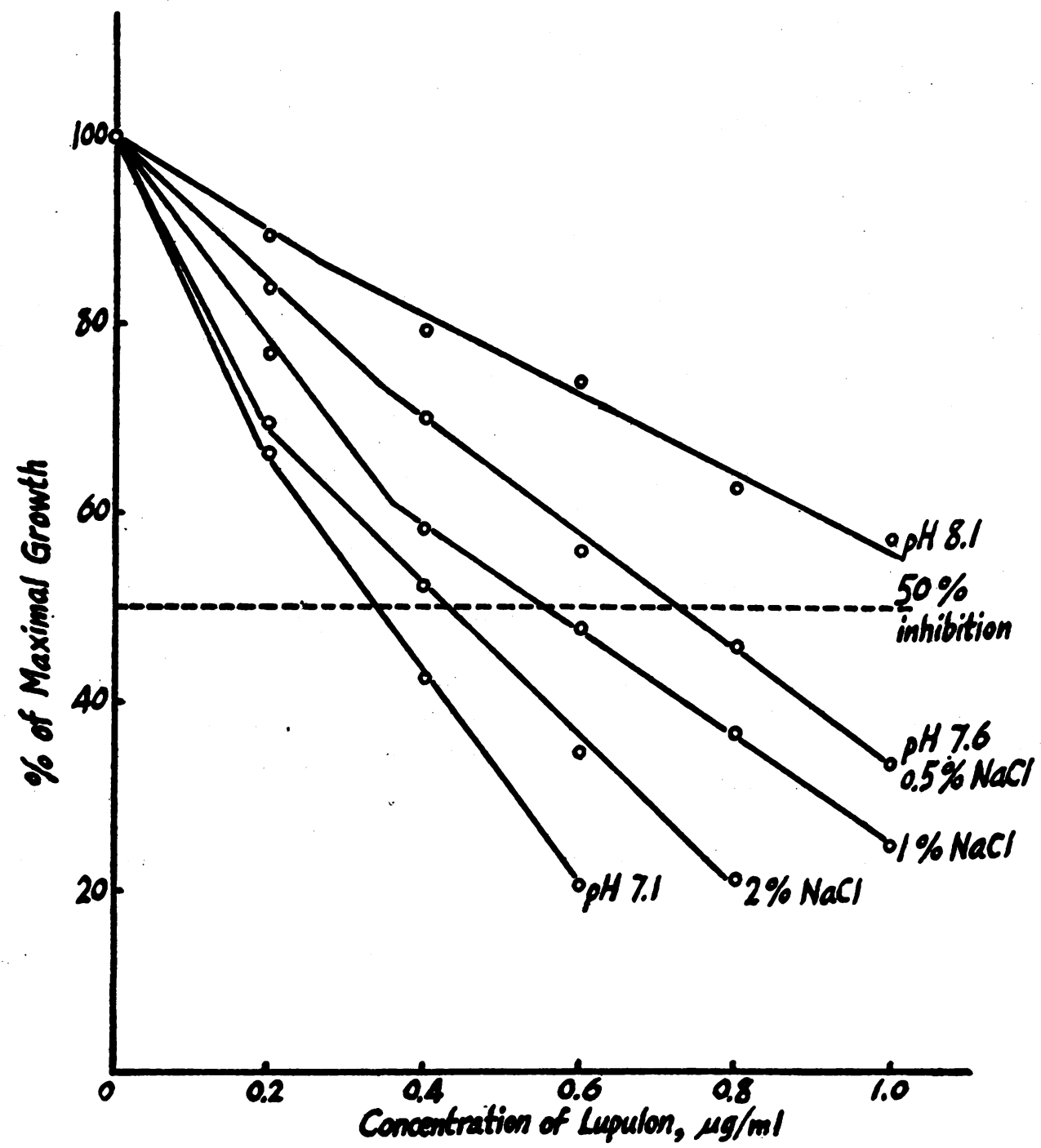

Fig. 1. Effect of PH and NaCl on Growth of Staph. aureus in Various Concentrations OF LUPULON 
TABLE III

The effect of $\mathrm{NaCl}$ in Dubos fuid medium on the growth of $M$. tuberculosis (H37Rv) in various concentrations of lupulon

\begin{tabular}{|c|c|c|c|c|c|c|c|c|}
\hline \multirow{2}{*}{$\begin{array}{l}\text { Concen- } \\
\text { tration } \\
\text { of } \mathrm{NaCl} \\
\%\end{array}$} & \multicolumn{8}{|c|}{ Concentrations of lupulon, $\mu \mathrm{g} . / \mathrm{ml}$. } \\
\hline & 40 & 30 & 25 & 20 & 15 & 10 & $\mathbf{5}$ & $\mathbf{0}$ \\
\hline $\begin{array}{l}0 \\
0.5 \\
1.0 \\
2.0\end{array}$ & $=$ & $\bar{z}$ & $=$ & $\begin{array}{r}++ \\
+ \\
\pm\end{array}$ & ++ & & $\begin{array}{l}++ \\
+t+ \\
+t \\
++\end{array}$ & \\
\hline
\end{tabular}

antibiotic activity of lupulon against $M$. tuberculosis (H37Rv) (Table III).

\section{Effect of serum}

Studied with M. tuberculosis (H37Rv). Pooled human serum, Seitz-filtered and inactivated at $56^{\circ} \mathrm{C}$. for 30 minutes, was added to Dubos medium at three different concentrations, namely, 5 , 7 , and $10 \%$. Similarly treated horse serum was used at $10 \%$. Since Dubos medium containing $20 \%$ of either human or horse serum became turbid and then produced sediments after 24 hours incubation at $37^{\circ} \mathrm{C}$. which interfered with reading the end points, this concentration was not included in the present study. The results of repeated experiments by serial dilution method showed consistently that the growth of tubercle bacilli was completely inhibited by lupulon at a concentration of $1: 40,000$ or $25 \mu \mathrm{g} . / \mathrm{ml}$. regardless of the presence of either serum up to $10 \%$.

Studied with M. phlei. Table IV shows the effect of various concentrations of inactivated horse serum on the bacteriostatic level of lupulon against $M$. phlei. In the presence of $10 \%$ serum the growth was completely inhibited by $70 \mu \mathrm{g} . / \mathrm{ml}$. instead of $50 \mu \mathrm{g} . / \mathrm{ml}$. in its absence. There was, therefore, an apparent $30 \%$ reduction of the activity.

Studied with Staph. aureus. By the serial dilu- tion method, using $1: 1,000$ dilution of 24-hour culture for inoculation, the concentration of lupulon which caused complete inhibition of growth of this bacteria in veal-glucose medium containing $10 \%$ inactivated horse serum was $12.5 \mu \mathrm{g} . / \mathrm{ml}$. in contrast to $1: 640,000$ or $1.56 \mu \mathrm{g} . / \mathrm{ml}$. in the absence of the serum. The activity of lupulon was apparently reduced to about one-tenth of its original level.

Turbidimetric and plate-well assay were then performed to give this effect a further analysis. In turbidimetry, six duplicate series of six tubes containing various amounts of lupulon were prepared as described previously in this paper. In five of such series the medium contained five different concentrations of inactivated horse serum, namely, $50,20,10,5$, and $2 \%$. The sixth series served as the control without serum. The results, as shown in Figure 2, indicated that there was a reduction of the activity of lupulon to one-tenth. The growth of Staph. aureus was practically not inhibited by lupulon in the presence of $50 \%$ serum.

For plate assay, $0.9 \% \mathrm{NaCl}$ was adjusted to $\mathrm{pH}$ 11.5. Inactivated horse serum was added to it at 2,10 , and $50 \%$. Lupulon was diluted in these solutions at $50,20,10$, and $5 \mu \mathrm{g} . / \mathrm{ml}$. It was also diluted in $100 \%$ serum as well as the saline without serum. The inhibition zone was plotted against the logarithm of the concentrations (Figure 3). That produced by $50 \mu \mathrm{g} . / \mathrm{ml}$. in $100 \%$ serum was of approximately the same size as one produced by $5 \mu \mathrm{g} . / \mathrm{ml}$. in saline. The inhibitory power of lupulon in $10 \%$ serum was about $30 \%$ of that in its absence; in contrast, only one-tenth was found in the fluid medium as determined by serial dilution or turbidimetric method.

The apparently dissimilar effect of serum on the antibiotic activity of lupulon against different bacteria as well as against the same bacteria in dif-

TABLE IV

The effect of horse serum in Dubos medium on the growth of M. phlei in various concentrations of lupulon

\begin{tabular}{|c|c|c|c|c|c|c|c|c|c|c|}
\hline \multirow{2}{*}{$\begin{array}{c}\text { Concentration } \\
\text { of serum } \\
\%\end{array}$} & \multicolumn{10}{|c|}{ Concentration of lupulon, $\mu \mathrm{g} . / \mathrm{ml}$. } \\
\hline & 80 & 70 & 60 & 55 & 50 & 45 & 40 & 35 & 30 & $\mathbf{0}$ \\
\hline $\begin{array}{r}0 \\
2 \\
5 \\
10\end{array}$ & $\begin{array}{l}\overline{-} \\
\overline{-}\end{array}$ & $\begin{array}{l}\bar{z} \\
\overline{-}\end{array}$ & $\frac{\bar{z}}{\bar{t}+}$ & $\begin{array}{l}\bar{t} \\
\dot{t}+\end{array}$ & $\bar{z}$ & & + & & 1 & L. \\
\hline
\end{tabular}




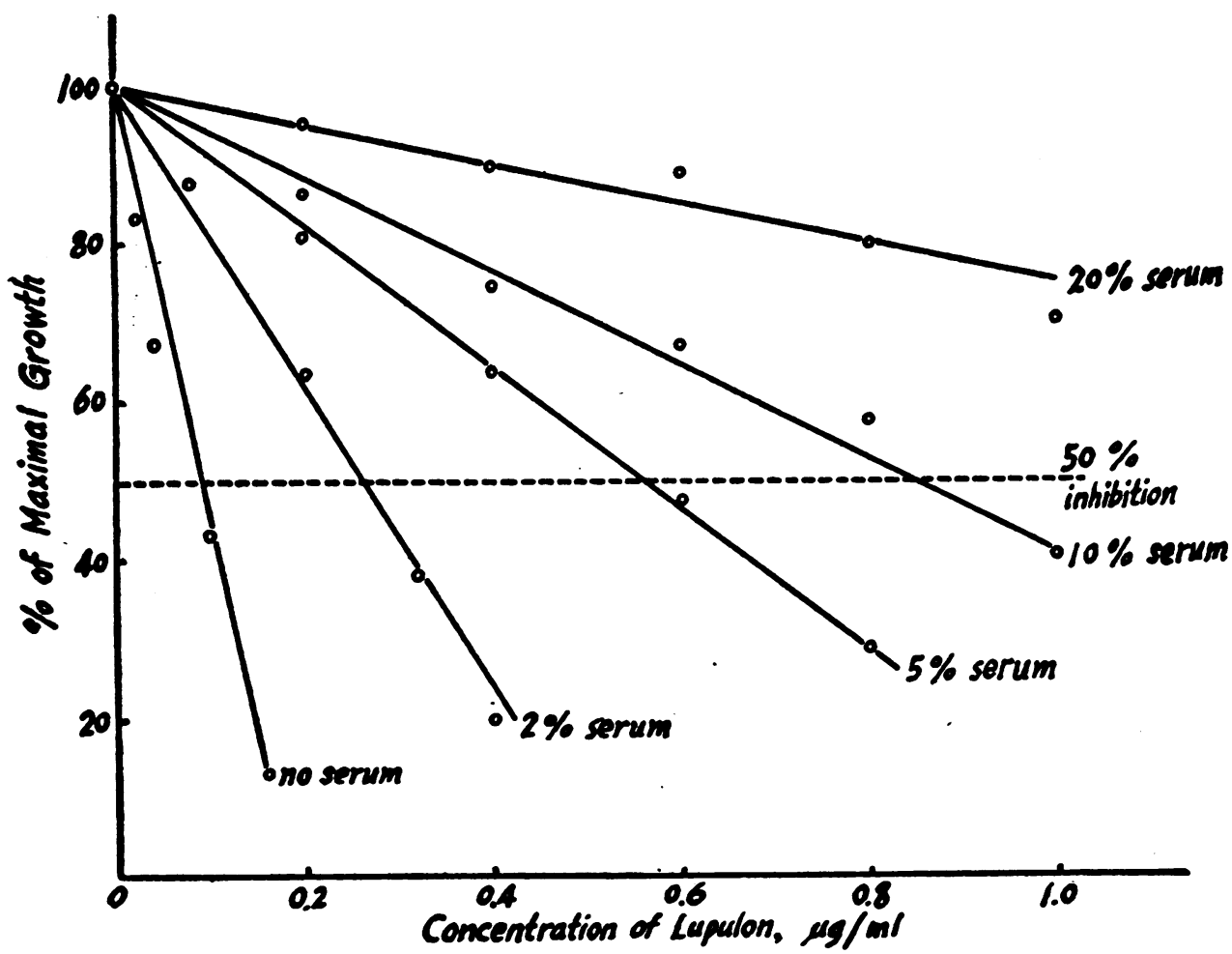

Fig. 2. Efrect of Horse Serum on Growtr of Staph. aureus in Various Concentrations OF LUPULON

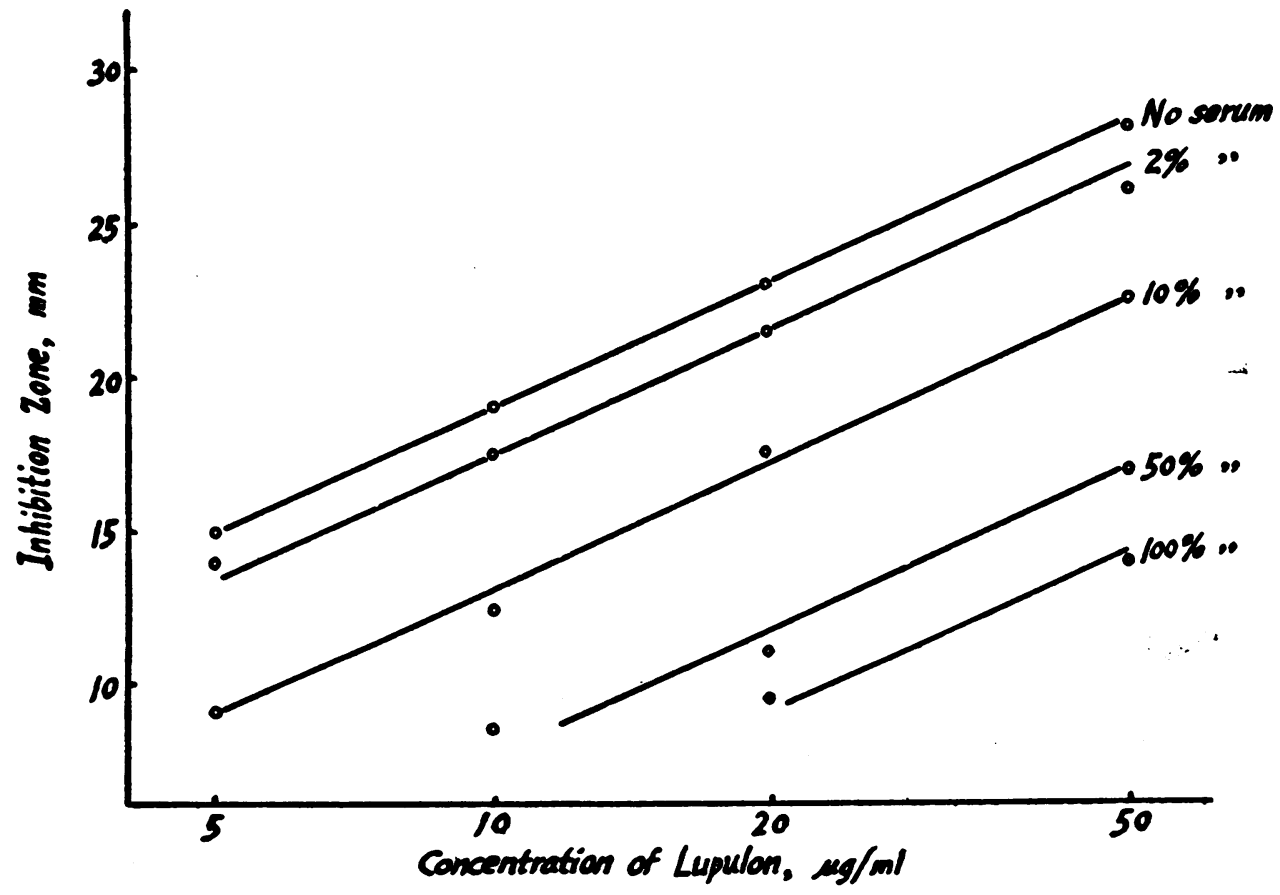

Fig. 3. Effect of Horse Serum on Activity of Lupulon by Plate-Well Assay against Staph. aureus 
ferent media indicated that the effect was unlikely exerted on the antibiotic itself. This point was substantiated by the following experiment.

A $1,000 \mu \mathrm{g} . / \mathrm{ml}$. solution of lupulon in inactivated horse serum $(A)$ and another in alkaline water (B) were made from $1 \%$ propylene glycol solution. After 24 hours, a fresh solution of each ( $C$ and $D$ ) was prepared from the same propylene glycol solution. Thirty minutes later, equal volumes of $95 \%$ ethyl alcohol were added to all tubes, and those containing serum were centrifuged to separate the precipitates. The supernatant fluid and the alkaline-alcohol solution were diluted to $50,20,10$, and $5 \mu \mathrm{g} . / \mathrm{ml}$. of lupulon, calculated on the basis of the amount originally added to the solutions before adding ethyl alcohol. A series of alkaline solutions (E) diluted from the same propylene glycol preparation and another series of similar dilutions of the solvents only (F). served as controls. Each series of dilutions was assayed by duplicate plates. It was definitely shown (Table V) that all the activity of lupulon was retained in the supernatant fluid. It is, therefore, believed that whatever the serum contained which produced the apparent reduction in the activity of lupulon had been removed by precipita-

TABLE $V$

The results of plate-well assay of the supernatant fluids after precipitation of proteins from lupulon solutions in horse serum with $48 \%$ ethyl alcohol

\begin{tabular}{|c|c|c|c|c|}
\hline \multirow[t]{2}{*}{ Solution assayed } & \multicolumn{4}{|c|}{$\begin{array}{l}\text { Concentration of lupulon, based on the } \\
\text { amount originally present in the } \\
\text { solutions before adding ethyl } \\
\text { alcohol, in } \mu \mathrm{g} . / \mathrm{ml} \text {. }\end{array}$} \\
\hline & 50 & 20 & 10 & 5 \\
\hline . & \multicolumn{4}{|c|}{$\begin{array}{l}\text { Average diameter of inhibition zones } \\
\text { in } \mathrm{mm} \text {. }\end{array}$} \\
\hline $\begin{array}{l}\text { Supernatant (A) after } \\
\text { precipitation of pro- } \\
\text { teins }\end{array}$ & 27.5 & 22.5 & 19.5 & 16 \\
\hline $\begin{array}{l}\text { (B) }+ \text { equal volume of } \\
95 \% \text { alcohol }\end{array}$ & 28 & 23 & 20.2 & 16.5 \\
\hline $\begin{array}{l}\text { Supernatant (C) after } \\
\text { precipitation of pro- } \\
\text { teins }\end{array}$ & 28 & 23.2 & 19.5 & 16.2 \\
\hline $\begin{array}{l}\text { (D) }+ \text { equal volume of } \\
95 \% \text { alcohol }\end{array}$ & 28.2 & 22.7 & 19.7 & 16.2 \\
\hline $\begin{array}{l}\text { Alkaline solutions (E) } \\
\text { without alcohol }\end{array}$ & 27.5 & 22.7 & 19.5 & 16 \\
\hline Solvent controls (F) & 0 & $\mathbf{0}$ & $\mathbf{0}$ & 0 \\
\hline
\end{tabular}

tion with $48 \%$ ethyl alcohol. When the same supernatant and alkaline-alcohol solutions were tested by serial dilution method the same end points were obtained.

\section{DISCUSSION}

Just how far the design of in vitro experiments on antibacterial agents can simulate the conditions in vivo is not certain. However, a stidy of the effect of such factors as $\mathrm{pH}$, sodium chloride, and serum gives information regarding the activity of these agents before or when they act on bacteria. Such a study on lupulon has indicated that at the $\mathrm{pH}$, the concentration of sodium chloride, and the presence of serum, which are normal to the body, this antibiotic remained active.

Lupulon is less soluble in water but more so in lipids at low $\mathrm{pH}$. The greater partition coefficient, therefore, may serve as an explanation for its availability to the bacterial cells (10) and thus its greater antibacterial activity at lower $\mathrm{pH}$. Penicillin is also more active at lower, and less at higher $\mathrm{pH}$, which Abraham and Duthie (11) suggested as an explanation of the action of penicillin by competition with $\mathrm{OH}^{-}$ions for position on the cell surface in order to produce its effect. A similar theory might be suggested, also for lupulon on account of the above-mentioned facts.

Addition of sodium chloride to the media increased slightly the antibiotic activity of lupulon. In no case was it decreased, although the presence of the salt in lupulon solution assayed on plates produced no effect at all. Such minor discrepancy may be explained on the basis of a difference in the rate of diffusion as in the case of streptomycin (12).

That lupulon is not inactivated by serum has been shown by the fact that it retained activity after standing in serum solution for 24 hours. The apparent effect of serum on the antibiotic activity must be explained either by a change of sensitivity of the bacteria or by the presence of some antagonizing factors in the serum. No attempt has been made to elucidate this point. However, it is known that the apparent effect could be removed by treating solutions with $48 \%$ ethyl alcohol, whatever. its causal agent may be. It is unlikely that the effect was due to growth promotion by serum, because it has been found that the same 
bacteriostatic level of lupulon against Staph. aureus was obtained from three different media which supported its growth to varying degrees.

The apparent activity of streptomycin varied inversely with the size of inoculum, which Berkman et al. (13) explained to be due to the presence of a greater number of resistant organisms in a larger inoculum. This explanation has been adopted here, with reservation, for a similar finding with lupulon.

\section{SUM MARY}

Lupulon inhibits the growth of Staph. aureus (FDA No. 209), $M$. phlei and $M$. tuberculosis (H37Rv) at a concentration of $1.56,50$, and 25 $\mu \mathrm{g} . / \mathrm{ml}$., respectively. In the case of Staph. aureus a higher concentration is required for a larger inoculum. It is more active at low $\mathrm{pH}$. Sodium chloride at a concentration of $2 \%$ increases slightly its activity.

Its potency against $M$. tuberculosis is not affected by $10 \%$ horse or human serum. However, a $30 \%$ decrease has been observed under the same conditions for $M$. phlei. The activity against Staph. aureus has been estimated by serial dilution and turbidimetric methods to be reduced to one-tenth of its original level in $10 \%$ horse serum. By plate-well assay a similar reduction has been observed in 100\% serum. All the activity of lupulon has been found to be retained in the supernatant fluid after precipitation of proteins from solution in horse serum with $48 \%$ ethyl alcohol. These observations argue against any inactivation of lupulon by serum.

The results of this experiment indicate that under the conditions of the $\mathrm{pH}$, the concentration of sodium chloride, and the presence of serum, which are normal to the body, lupulon should remain active.

\section{BIBLIOGRAPHY}

1. Michener, H. D., Snell, N., and Jansen, E. F., Antifungal activity of hop resin constituents and a new method for isolation of lupulon. Arch. Biochem., 1948, 19, 199.

2. Lewis, J. C., Alderton, G., Carson, J. F., Reynolds, D. M., and Maclay, W. D., Lupulon and humulon antibiotic constituents of hops. J. Clin. Invest., 1949, 28, 916.

3. Salle, A. J., Jann, G. J., and Ordanik, M., Personal communication, 1948.

4. Shimwell, J. L., On the relation between the staining properties of bacteria and their reaction towards hop antiseptic. J. Inst. Brewing, 1937, 13 (34), 111.

5. Chin, Y. C., Anderson, H. H., Alderton, G., and Lewis, J. C., The antituberculous activity and toxicity of lupulon for the mouse. Proc. Soc. Exper. Biol. \& Med., 1949, 70, 158.

6. Chin, Y. C., and Anderson, H. H., Toxicology and pharmacology of lupulon. Submitted to Arch. internat. de pharmacodyn. et de thérap., 1949.

7. Joslyn, D. A., Penicillin assay, outline of four-hour turbidimetric method. Science, 1944, 99, 21.

8. Dubos, R. J., and Davis, B. D., Factors affecting the growth of tubercle bacilli in liquid media. J. Exper. Med., 1946, 83, 409.

9. Pratt, R., and Dufrenoy, J., Practical three-hour and two-hour cylinder-plate assays for penicillin. Nature, 1947, 159, 576.

10. Daniels, T. C., Synthetic drugs. Ann. Rev. Biochem., 1943, 12, 447.

11. Abraham, E. P., and Duthie, E. S., Effect of $\mathrm{pH}$ on the medium on activity of streptomycin and penicillin and other chemotherapeutic substances. Lancet, 1946, 1, 455.

12. Quan, S. F., The effects of salts on streptomycin and dihydrostreptomycin in agar plate assays. J. Bact., 1948, 55, 25.

13. Berkman, S., Henry, R. J., and Housewright, R. D., Studies on streptomycin. I. Factors influencing the activity of streptomycin. J. Bact., 1947, 53, 567. 